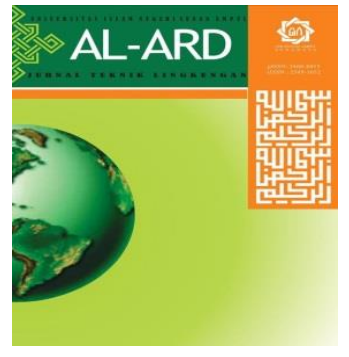

Al-Ard: Jurnal Teknik Lingkungan

Vol.5 No.2 - Maret 2020 (hal. 70-79)

http://jurnalsaintek.uinsby.ac.id/index.php/alard/index
Al-Ard:

Jurnal

Teknik Lingkungan

\title{
Analisis Faktor yang Mempengaruhi Perilaku Masyarakat untuk Berpartisipasi dalam Program Citarum Harum Aulia F. Hadining ${ }^{1}$, Kusnadi ${ }^{2}$, Gina Lova Sari ${ }^{3}$, Hadi Sudarjat ${ }^{4}$ \\ 1,23,4 Universitas Singaperbangsa Karawang, Indonesia aulia.fasha@staff.unsika.ac.id
}

\begin{abstract}
The behavior of people who depend on the Citarum River Watershed (DAS Citarum) in disposing of waste has a direct impact on the damage and pollution experienced by the Citarum River. Therefore, the Citarum Harum program by the government is expected to change the Citarum River Watershed (DAS Citarum) community more importantly in terms of waste management. The purpose of this study is to determine the factors that influence the behavioral intention of the Citarum watershed community to realize the Citarum Harum. This research was conducted by surveying through questionnaires to 170 respondents. After collecting data, the data then processed using Partial Least Square (PLS) method with SmartPLS 3.0 software. The results of this study indicate that the Perceived Behavioral Control (PBC), Incentive Measure (IM), and Personal Norm (PN) factors significantly influence the Behavioral Intention (BI) respectively amount 16.3\%, 15.9\%, and 19.1\%. While the Knowledge Theory (ETK) and Environmental Practices Knowledge factors influence the Attitude Towards Behavior (ATT) to understand in actualize citarum harum program respectively amount 38.4\% and $21.7 \%$.
\end{abstract}

Keywords: Behavioral Intention, Citarum Harum, Theory of Planned Behavior

\begin{abstract}
Abstrak
Perilaku masyarakat yang berada pada Daerah Aliran Sungai (DAS) sungai citarum dalam membuang sampah, memberikan pengaruh secara langsung terhadap kerusakan dan pencemaran yang dialami oleh sungai citarum. Maka dari itu, program citarum harum diharapkan mampu mengubah perilaku masyarakat DAS Citarum terutama dari segi pengelolaan sampah. Tujuan dari penelitian ini adalah untuk mengetahui faktor-faktor yang memengaruhi dan secara signifikan berpengaruh terhadap behavioral intention (niat perilaku) masyarakat DAS citarum untuk mewujudkan citarby theum harum. Penelitian ini dilakukan dengan survei melalui kuesioner kepada 170 responden. Setelah dilakukan pengumpulan data, kemudian data tersebut diolah menggunakan metode Partial Least Square (PLS) dengan software SmartPLS 3.0. Hasil dari penelitian ini menunjukkan bahwa faktor Perceived Behavioral Control (PBC), Incentive Measure (IM), dan Personal Norms (PN) secara signifikan berpengaruh positif terhadap Behavioral Intention (BI) masing-masing sebesar 16,3\%, 15,9\%, dan 19,1\%. Sedangkan faktor Environment Theory Knowledge (ETK) dan Environment Practice Knowledge memberikan pengaruh terhadap Attitude Toward the Behavior (ATT) untuk berpartisipasi dalam mewujudkan citarum harum masing-masing sebesar 38,4\% dan 21,7\%.

Kata Kunci: Behavioral Intention, Citarum Harum, Theory of Planned Behavior
\end{abstract}

\section{PENDAHULUAN}

Beberapa tahun terakhir permasalahan limbah sudah menjadi persoalan krusial di sejumlah negara termasuk Indonesia. Berbagai aktivitas manusia yang berasal dari kegiatan rumah tangga, industri, peternakan, pertanian, perikanan pada dasarnya akan menghasilkan limbah. Berkaitan dengan pembuangan limbah apabila dibuang langsung ke lingkungan akan menjadi penyebab utama p-ISSN: 2460-8815, e-ISSN: 2549-1652 terjadinya pencemaran terhadap lingkungan (Pavita, Widiatmono, \& Liliyana, 2014).

Masalah pencemaran lingkungan yang sampai saat ini belum teratasi yaitu pencemaran Sungai Citarum. Ramai menjadi perbincangan di berbagai media bahwa Sungai Citarum menjadi salah satu sungai paling tercemari di dunia (Van Ginkel, Ozerol, \& Lutfiandi, 2015). Daerah Aliran Sungai (DAS) Citarum sebagai salah satu sungai terbesar 
dan terpanjang di Jawa Barat dan secara geografis melewati beberapa kabupaten yaitu Bandung Barat, Cianjur, Purwakarta, dan Karawang sekaligus rumah bagi 3 bendungan besar yaitu Jatiluhur, Cirata, dan, Saguling (BBWS, 2014). Kerusakan dan pencemaran yang dialami Sungai Citarum sudah sangat kritis. Berdasarkan pemantauan kualitas air dari Kemenko Maritim pada tahun 2017, menunjukkan beban pencemaran pada kualitas air eksisting Sungai Citarum saat ini berada dalam katagori tercemar berat (Syafila \& Marselina, 2018).

Kementerian Lingkungan Hidup menjabarkan bahwa sumber pencemaran Sungai Citarum yang diukur dengan indikator Biochemical Oxygen Demand (BOD) berasal dari limbah domestik (air limbah rumah tangga dan sampah), industri (gabungan sumber pencemar institusi yaitu industri, rumah sakit, hotel, dan UMKM), perikanan, peternakan, dan non-point source (pertanian, hutan dan lahan terbangun di perkotaan) (Kementrian LH, 2018). Presentase sumber pencemar di DAS Citarum dapat dilihat pada Gambar 1.

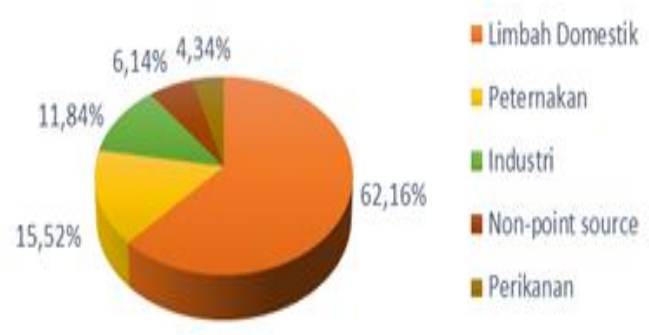

Gambar 1 Presentase penyebab pencemaran DAS Citarum

(Sumber: Syafila \& Marselina, 2018)

Pada Gambar 1, diketahui limbah domestik memiliki prosentase terbesar dan menjadi sumber pencemar paling banyak di DAS Citarum. Limbah domestik tersebut berasal dari kegiatan masyarakat (mandi, cuci, kakus (MCK), sisa-sisa makanan dan sayuran, sampah plastik) di sekitar DAS Citarum. Hal ini berarti semakin tinggi kepadatan penduduknya semakin besar beban pencemar domestik yang ditimbulkan (Syafila \& Marselina, 2018). Selain itu, UKM juga berperan menyumbangkan limbah seperti Keramba Jaring Apung (KJA) yang terdapat di perairan Waduk Jatiluhur menjadi penyebab penurunan kualitas air sebesar 7,87\% antara tahun 2014 dan 2019 (Prinajati, 2019). Pencemaran di Waduk Jatiluhur didominasi oleh limbah bahan organik dari populasi keramba jaring apung yang sudah melebihi batas misal dari sisa pakan ikan (Anas, Jubaedah, \& Sudino, 2017).

Desa Cikaobandung termasuk dalam wilayah Dansektor 14 dan terletak dekat dengan Waduk Jatiluhur. Berdasarkan letak geografis, Desa Cikaobandung dilintasi oleh aliran Sungai Citarum dan terhubung dengan perairan Waduk Jatiluhur. Desa Cikaobandung merupakan desa yang berlokasi tepat di aliran sungai citarum dan keluaran waduk jatiluhur. Hal ini membuat desa Cikaobandung dialiri oleh sungai yang tercemar dari berbagai sumber yaitu limbah industri, KJA Waduk Jatiluhur, dan terutama limbah domestik. Oleh karena itu responden pada penelitian ini adalah warga desa yang tinggal di desa Cikaobandung.

Pencemaran Citarum juga disebabkan oleh paradigma masyarakat yang menganggap sungai merupakan tempat sampah raksasa dan destinasi akhir semua jenis kotoran (Zakia, et al., 2019). Dampak pencemaran lingkungan di sekitar DAS Citarum juga akan berdampak pada kesehatan masyarakat sekitar. Penggunaan air citarum yang masih tercemar dapat menyebabkan berbagai penyakit, contohnya diare, penyakit kulit, saluran pernapasan dan lainnya (Erianti \& Djelantik, 2019)

Berbagai permasalahan yang telah dipaparkan membutuhkan upaya penanganan yang tepat dimana menurut Perpres Nomor 15 Tahun 2018 pasal 13 (b) diperlukan adanya pemulihan ekosistem melalui inovasi inovasi perbaikan berkelanjutan. Guna merencanakan dan merekayasa upaya tersebut dibutuhkan data -data mengenai perilaku serta kesadaran masyarakat terhadap lingkungan.

Perilaku masyarakat terhadap lingkungan memegang peranan penting dalam penanganan pencemaran dan terlaksananya program Citarum Harum karena aktor utamanya adalah masyarakat DAS Citarum yang terlibat secara langsung, khususnya mengenai pengelolaan sampah (Erianti \& Djelantik, 2019). Selain itu perilaku juga menunjukkan kepedulian dan komitmen masyarakat sebagai bentuk partisipasi terhadap program Citarum Harum.

Berdasarkan pemaparan tersebut, model Theory of Planned Behavior (TPB) yang dibangun oleh Ajzen (1985) merupakan 
pengembangan dari model TRA (Theory of Reasoned Action), menjadi model penelitian yang banyak digunakan untuk menjelaskan dan memprediksi niat dan perilaku seseorang dalam berbagai konteks permasalahan khususnya mengenai penelitian yang berkaitan dengan lingkungan (Han, 2015).

Model TPB yang dikembangkan oleh $\mathrm{Hu}$ berfokus kepada behavioral intention seseorang untuk berpartisipasi dalam program peduli lingkungan yang selaras dengan konteks penelitian ini (Hu, Zhang, Wang, Yu, \& Chu, 2019). Banyak penelitian menemukan bahwa kerangka model TPB dapat diperdalam dan diperluas penjabarannya (Hu dkk, 2018).

Tujuan dari penelitian ini adalah untuk menganalisis faktor - faktor yang memengaruhi behavioral intention masyarakat untuk berpartisipasi dalam program Citarum Harum.

\subsection{Model Penelitian dan Hipotesis}

$\mathrm{Hu}$ menggunakan Theory of Planned Behavior untuk mengembangkan model teoritis yang lebih prediktif dari model asli sesuai dengan tujuan penelitian ( $\mathrm{Hu}$ dkk, 2019). Pada penelitian ini model dikembangkan berdasarkan tujuan penelitian yang hendak dicapai yaitu mengetahui faktor Theory of Planned Behavior yang berpengaruh terhadap Behavioral Intention masyarakat untuk berpartisipasi dalam program Citarum Harum.

Pada model yang dibentuk oleh $\mathrm{Hu}$ (Hu dkk, 2018, 2019) variabel terdiri dari Attitude Toward The Behavior (ATT), Subjective Norms (SN), Perceived Behavioral Control (PBC), Incentive Measures (IM), Environmental Theory Knowledge (ETK), Environmental Practice Knowledge (EPK), Government Companion (GC), Personal Norms (PN), dan Past Behavior (PB). Defnisi dari masing-masing variabel adalah:

a. Attitude Toward The Behavior (ATT)

Attitude Toward The Behavior merupakan variabel yang menunjukkan suatu kecenderungan sikap seseorang dalam menghadapi hal-hal yang disukai atau tidak disukai pada sebuah objek individu, institusi, atau peristiwa (Ajzen, 2011). Menurut Ajzen (1991) dalam Hu dkk (2018) attitude toward the behavior ditentukan oleh keyakinan seseorang mengenai konsekuensi atau evaluasi hasil yang akan ditimbulkan dari melakukan suatu perilaku (behavioral beliefs).

b. Subjective Norms (SN),

Menurut Ajzen (1991) dalam Hu dkk (2018) subjective norms atau norma subjektif didefinisikan sebagai suatu tingkatan persepsi seorang individu bahwa kebanyakan orang yang penting baginya berpikir individu tersebut seharusnya atau tidak seharusnya melakukan perilaku yang ingin ditunjukkan.

c. Perceived Behavioral Control (PBC),

(Ajzen, From intentions to action: a theory of planned behavior, 1985) dalam $\mathrm{Hu}$ dkk, (2019) mengartikan sebagai suatu tingkat kepercayaan seorang individu terhadap kemudahan atau kesulitan dalam melakukan sesuatu. Seseorang akan melakukan suatu perilaku ketika mereka memiliki persepsi bahwa perilaku tersebut mudah untuk ditunjukkan atau dilakukan karena adanya hal-hal/faktor yang mendukung atau memfasilitasi perilaku tersebut.

d. Incentive Measures (IM)

Incentive measures merupakan salah satu faktor ekonomi atau non ekonomi yang akan memengaruhi seseorang dalam berperilaku dan akan membuat perilaku peduli lingkungan lebih menarik dan menyenangkan untuk dilakukan $(\mathrm{Hu}, \mathrm{dkk}$., 2018). Karena faktor ekonomi (kompensasi, uang, dll) merupakan faktor yang sangat penting dan secara postif dapat mengubah perilaku seseorang ketika berhadapan dengan sebuah hal baru, seperti sebuah program khususnya mengenai program peduli lingkungan (Hu, dkk., 2019, 2018). Dan juga faktor non ekonomi seperti pemberian sebuah penghargaan juga mempengaruhi individu atau sesorang dalam menghadapi sebuah pilihan untuk mengikuti atau tidak sebuah program atau sesuatu yang baru bagi mereka $(\mathrm{Hu}$, dkk., 2019).

e. Environmental Theory Knowledge (ETK) Enviromental Theory Knowledge adalah cakupan pengetahuan secara umum mengenai fakta, konsep dan hubungan antara lingkungan alam dan ekosistem yang ada didalamnya (Fryxell \& Lo, 2003). Menurut Hu, dkk. (2019) Enviromental 
Theory Knowledge adalah pengetahuan teoritis mengenai lingkungan beserta dampak lingkungan terhadap kehidupan sosial dan alam itu sendiri.

f. Environmental Practice Knowledge (EPK), Enviromental Practical Knowledge menurut $\mathrm{Hu}$, dkk., (2019) adalah kemampuan mempraktikan suatu program.

g. Government Companion (GC)

Definisi Goverment Companion diadaptasi dari Travel Companion yang menurut $\mathrm{Hu}$, dkk., (2019) didefiniskan sebagai rekan berpergian atau dapat dikatakan sebagai subjek lain yang berfungsi sebagai faktor moderasi yang turut memengaruhi subjective norm seseorang dalam berperilaku atau melakukan sesuatu.

h. Personal Norms (PN)

Schwartz dan Howard (1981) mendefiniskan personal norms sebagai moral obligation (kewajiban moral) untuk melakukan atau tidak melakukan sesuatu, menurut Hu, dkk. (2019) personal norms adalah dorongan internal dari dalam diri yang dapat mempengaruhi perilaku individu sehingga mampu menyadari kondisi spesifik guna menghindari konsekuensi merugikan nantinya $(\mathrm{Hu}$, dkk., 2019)

i. Past Behavior (PB)

(Schwartz \& Howard, 1981)Past Behavior adalah perilaku di masa lalu (Hu, dkk., 2019). Azjen (2011) dan Hu, dkk. (2019) menemukan bahwa past behavior merupakan prediktor yang baik untuk menentukan behavioral intention karena past behavior merupakan kunci utama yang berperan meningkatkan dan menguatkan hasil Theory Planned Behavior.

Model penelitian ditunjukkan pada Gambar 2.

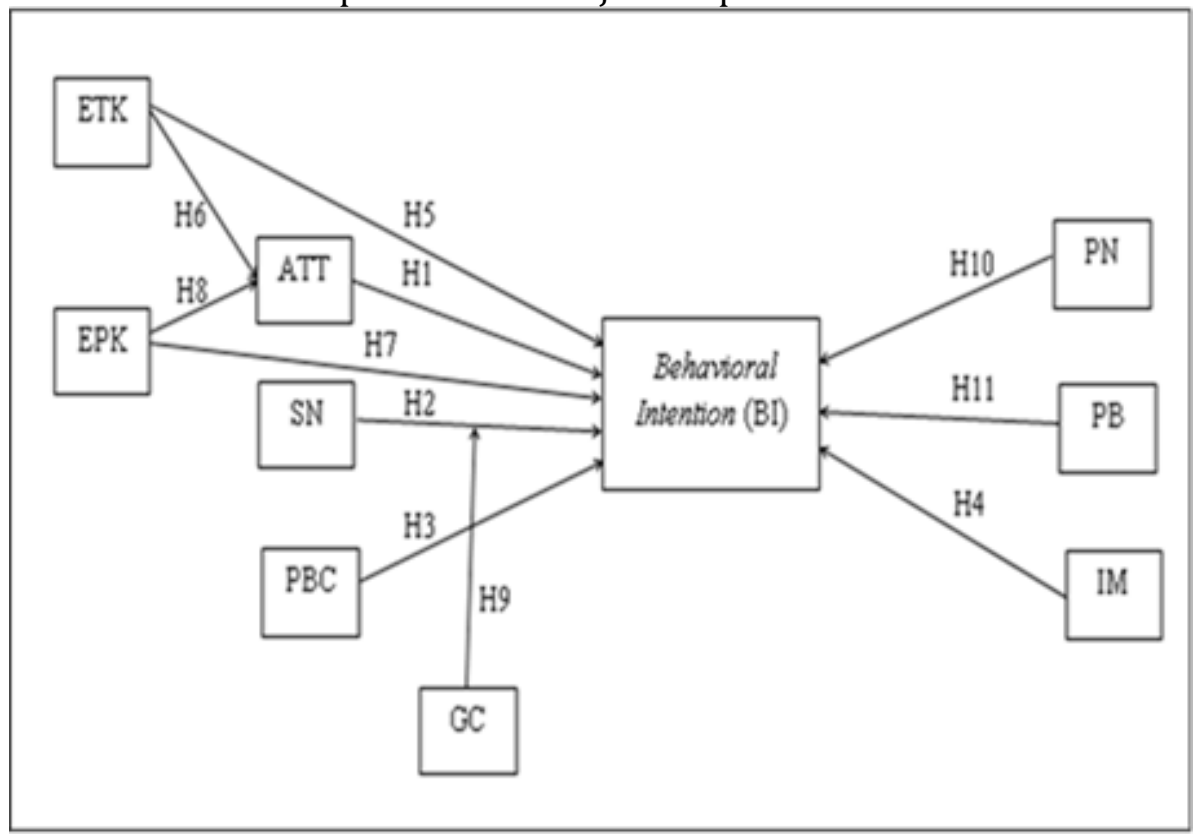

Gambar 2. Model Penelitian (Sumber: Hu dkk, 2019)

Hipotesis yang digunakan dalam penelitian ini berdasarkan model penelitian pada Gambar 2 adalah sebagai berikut:

a. Hipotesis 1: Attitude Toward The Behavior secara signifikan berpengaruh positif terhadap Behavioral Intention masyarakat untuk berpartisipasi dalam program Citarum Harum.

b. Hipotesis 2: Subjective Norms secara signifikan berpengaruh positif terhadap Behavioral Intention masyarakat untuk berpartisipasi dalam program Citarum Harum.

c. Hipotesis 3: Perceived Behavioral Control secara signifikan berpengaruh positif terhadap Behavioral Intention masyarakat untuk berpartisipasi dalam program Citarum Harum.

d. Hipotesis 4: Incentive Measures secara signifikan berpengaruh positif terhadap Behavioral Intention masyarakat untuk berpartisipasi dalam program Citarum Harum. 
e. Hipotesis 5: Environmental Theory Knowledge secara signifikan berpengaruh positif terhadap Behavioral Intention masyarakat untuk berpartisipasi dalam program Citarum Harum.

f. Hipotesis 6: Environmental Theory Knowledge memiliki pengaruh positif secara langsung terhadap attitude torward behavior masyarakat untuk berpartisipasi dalam program Citarum Harum.

g. Hipotesis 7: Environmental Practice Knowledge secara signifikan berpengaruh positif terhadap Behavioral Intention masyarakat untuk berpartisipasi dalam program Citarum Harum.

h. Hipotesis 8: Environmental Practice Knowledge memiliki pengaruh positif secara langsung terhadap attitude torward behavior masyarakat untuk berpartisipasi dalam program Citarum Harum.

i. Hipotesis 9: Government Companion secara signifikan berpengaruh positif terhadap Behavioral Intention masyarakat untuk berpartisipasi dalam program Citarum Harum.

j. Hipotesis 10: Personal Norms secara signifikan berpengaruh positif terhadap Behavioral Intention masyarakat untuk berpartisipasi dalam program Citarum Harum.

Hipotesis 11: Past Behavior secara signifikan berpengaruh positif terhadap Behavioral Intention masyarakat untuk berpartisipasi dalam program Citarum Harum.

\section{METODE PENELITIAN}

\subsection{Sampel Penelitian}

Populasi yang digunakan untuk penelitian ini adalah masyarakat yang tinggal disekitar DAS Citarum dan berdekatan dengan KJA Waduk Jatiluhur. Hal ini terkait dengan tujuan penelitian yaitu bertujuan untuk mengetahui faktorfaktor yang memengaruhi behavioral intention masyarakat untuk berpartisipasi dalam program Citarum Harum. Berdasarkan tujuan tersebut, penelitian ini menggunakan teknik pengambilan sampel secara purposif (purposive sampling). Menurut Sugiyono, purposive sampling adalah teknik penentuan sampel dengan pertimbangan tertentu. Pengambilan sampel penelitian dengan menggunakan metode tersebut sesuai untuk digunakan dalam penelitian ini.

Lokasi pengambilan sampel terletak di RW 02 Desa Cikaobandung, Jatiluhur, Kabupaten Purwakarta. Penentuan sampel menggunakan rumus slovin dengan taraf kesalahan sebesar 5\%. Jumlah populasi masyarakat RW 02 Desa Cikaobandung, Jatiluhur, Purwakarta yaitu 285 orang maka dapat diketahui jumlah sampel yang akan diteliti adalah sebanyak 170 orang.

\subsection{Instrumen Penelitian}

Pada penelitian ini, kuisioner terdiri atas dua bagian. Bagian pertama berisi informasi data diri responden (basic information of demographics) dan bagian kedua berisi pernyataan mengenai persepsi masyarakat untuk berpartisipasi dalam program Citarum Harum dari sepuluh variabel sebelumnya yaitu ETK, EPK, GC, ATT, SN, PBC, PB, PN, IM, dan BI. Pengukuran item pernyataan pada kuisioner menggunakan skala likert yang berisi lima tingkat preferensi jawaban mulai dari $1=$ sangat tidak setuju hingga $5=$ sangat setuju (Ghozali, 2016).

\subsection{Pengumpulan Data}

Survei pertama dilakukan dengan menyebarkan kuesioner pendahuluan (pilot project) kepada 30 sampel untuk selanjutnya dilakukan uji validitas dan reliabilitas. Hasil uji validitas dan reliabilitas terhadap 30 data pilot project adalah valid dan reliabel, maka survei dilakukan kembali kepada 140 responden lainnya.

Hingga pada batas akhir waktu penyebaran terkumpul 170 kuesioner yang disebarkan secara langsung kepada masyarakat desa. Berdasarkan hasil 170 kuesioner yang terkumpul terdapat 170 kuesioner yang dapat diolah karena tidak terdapat kekurangan kelengkapan jawaban dalam pengisian kuesioner.

\subsection{Metode Analisis Data}

Variabel yang ada pada model akan diuji secara kuantitatif dan divalidasi. Pengolahan dan analisis data dilakukan dengan uji kuantitatif menggunakan metode Partial Least Square (PLS) dengan bantuan software SmartPLS 3.0. Tahap pengolahan dengan metode SEM-PLS terbagi menjadi 2 tahap yaitu evaluasi 
model pengukuran dan evaluasi model struktural.

Evaluasi model pengukuran (outer model) digunakan untuk menilai validitas dan reliabilitas suatu konstruk. Uji validitas dibagi menjadi 2 bagian yaitu validitas konvergen dan validitas diskriminan. Tahapan selanjutnya adalah dengan melakukan evaluasi model struktural (inner model). Uji inner model dilihat berdasarkan nilai $r$-square, model fit, predictive relevance $\left(Q^{2}\right)$, dan koefisien jalur untuk mengetahui hasil hipotesis dari penelitian.

Data demografi pada penelitian ini dikelompokkan menjadi 5 karakteristik diantaranya jenis kelamin (laki-laki, perempuan), usia ( $<14$ tahun, 15-24 tahun, 25-44 tahun, 45-65 tahun, dan $>65$ tahun), pendidikan terakhir (SD, SMP, SMA/K, sedang berkuliah, Sarjana, dan tidak sekolah) penghasilan bulanan $(<500.000$, 500.000- 2.000.000, 2.000.000-3.500.000, 3.500.000-5.000.000, dan > 5.000.000) dan sumber informasi mengenai program Citarum Harum.

\section{HASIL DAN PEMBAHASAN}

\subsection{Evaluasi Model Pengukuran}

Evaluasi model pengukuran atau biasa disebut sebagai outer model merupakan suatu uji untuk menilai hubungan dari setiap indikator terhadap variabel laten (Ghozali, 2014). Evaluasi model pengukuran dilihat dengan nilai validitas dan reliabilitas pada setiap variabel. Partial Least Square (PLS) dalam melakukan pengujian validitasnya dibedakan menjadi 2 yaitu validitas konvergen dan diskriminan.

Validitas konvergen diukur dengan nilai loading dan nilai AVE. Suatu indikator dinyatakan valid jika nilai loading yang dihasilkan lebih dari 0,7 atau berada pada nilai 0,5 - 0,6 (Ghozali, 2014).

Terdapat 30 indikator yang digunakan dalam penelitian ini yaitu ETK1, ETK2, ETK3, EPK1, EPK2, EPK3, GC1, GC2, GC3, ATT1, ATT2, ATT3, SN1, SN2, SN3, PBC1, PBC2, PBC3, PB1, PB2, PB3, PN1, PN2, PN3, IM1, IM2, IM3, BI1, BI2, dan BI3. Berdasarkan hasil keluaran software SmartPLS 3.0, indikator IM1, PBC1, PN3, dan SN1 dinyatakan tidak valid karena nilai loading berada di bawah 0,7 ataupun tidak berada pada nilai 0,5 dan 0,6 sehingga indikator-indikator yang dinyatakan tidak valid tersebut dikeluarkan dari konstruk.

Average Variance Extracted (AVE) merupakan salah satu jenis pengukuran validitas konvergen dalam menilai sejauh mana konstruk laten dapat menjelaskan varian indikatornya (Hair dkk, 2017). Nilai AVE yang direkomendasikan harus di atas 0,5 (Hair dkk, 2019). Berdasarkan nilai AVE pada Tabel 1, dapat dilihat bahwa seluruh konstruk berada di atas nilai 0,5 artinya validitas konvergen telah terpenuhi. Reliabilitas suatu konstruk pada metode PLS, diukur dengan melihat nilai reliabilitas komposit. Suatu konstruk dapat dikatakan reliabel jika memiliki nilai composite reliability (CR) di atas 0,7 (Hair dkk, 2019). Berdasarkan Tabel 1, nilai composite reliability seluruh variabel laten lebih besar dari 0,7 artinya seluruh variabel telah reliabel.

Tabel 1. Nilai AVE dan Composite Reliability

\begin{tabular}{lcc}
\hline \multicolumn{1}{c}{ Variabel Laten } & AVE & Composite Reliability (CR) \\
\hline Attitude Toward The Behavior (ATT) & 0,731 & 0,891 \\
\hline Behavioral Intention (BI) & 0,698 & 0,873 \\
\hline Environmental Practice Knowledge (EPK) & 0,648 & 0,847 \\
\hline Environmental Theory Knowledge (ETK) & 0,639 & 0,842 \\
\hline Government Companion (GC) & 0,656 & 0,851 \\
\hline Government Companion (GC) * Subjective Norms (SN) & 0,503 & 0,855 \\
\hline Incentive Measures (IM) & 0,822 & 0,902 \\
\hline Past Behavior (PB) & 0,632 & 0,837 \\
\hline Perceived Behavioral Control (PBC) & 0,886 & 0,940 \\
\hline Personal Norms (PN) & 0,726 & 0,842 \\
\hline Subjective Norms (SN) & 0,759 & 0,860
\end{tabular}

(Sumber: Pengolahan Data, 2020)

Tabel 2. Validitas Diskriminan Heterotrait-Monotrait (HTMT)

\begin{tabular}{|c|c|c|c|c|c|c|c|c|c|c|c|}
\hline Variabel Laten & ATT & BI & EPK & ETK & GC & $\mathbf{G C} * \mathbf{S N}$ & IM & PB & PBC & PN & SN \\
\hline \multicolumn{12}{|l|}{ ATT } \\
\hline $\mathrm{BI}$ & 0,479 & & & & & & & & & & \\
\hline EPK & 0,313 & 0,198 & & & & & & & & & \\
\hline ETK & 0,464 & 0,291 & 0,098 & & & & & & & & \\
\hline GC & 0,578 & 0,515 & 0,203 & 0,429 & & & & & & & \\
\hline
\end{tabular}




\begin{tabular}{|c|c|c|c|c|c|c|c|c|c|c|c|}
\hline Variabel Laten & ATT & BI & EPK & ETK & GC & GC * SN & IM & PB & PBC & PN & SN \\
\hline $\mathrm{GC} * \mathrm{SN}$ & 0,113 & 0,178 & 0,111 & 0,077 & 0,144 & & & & & & \\
\hline IM & 0,162 & 0,229 & 0,096 & 0,115 & 0,053 & 0,11 & & & & & \\
\hline PB & 0,074 & 0,166 & 0,148 & 0,159 & 0,159 & 0,158 & 0,257 & & & & \\
\hline PBC & 0,101 & 0,235 & 0,133 & 0,102 & 0,075 & 0,133 & 0,235 & 0,242 & & & \\
\hline PN & 0,103 & 0,278 & 0,16 & 0,115 & 0,218 & 0,082 & 0,363 & 0,265 & 0,09 & & \\
\hline SN & 0,167 & 0,097 & 0,112 & 0,166 & 0,152 & 0,127 & 0,141 & 0,105 & 0,074 & 0,069 & \\
\hline
\end{tabular}

(Sumber: Pengolahan SmartPLS 3.0)

Validitas diskriminan diukur dengan menggunakan nilai Heterotrait-Monotrait (HTMT). Suatu model dikatakan tidak memiliki masalah validitas diskriminan, jika nilai HTMT berada di bawah 0,9 (Henseler, Ringle, \& Sarstedt, 2015). Berdasarkan hasil pada Tabel 2 dapat dilihat bahwa model ini memiliki validitas diskriminan yang baik karena nilainya berada di bawah 0,9. Hasil perthitungan yang disajikan pada Tabel 1 dan Tabel 2 menunjukkan bahwa seluruh variabel telah memenuhi uji model pengukuran validitas konvergen, validitas diskriminan, dan reliabilitas.

\subsection{Evaluasi Model Struktural}

Evaluasi model strukturan menggambarkan hubungan antar variabel laten yang dibedakan menjadi variabel eksogenus dan variabel endogenus (Ghozali, 2014). Model struktural diukur dengan melihat nilai model fit (SRMR), nilai $r$-square $\left(\mathrm{r}^{2}\right)$, predictive relevance $\left(\mathrm{Q}^{2}\right)$, dan koefisien jalur (Hair dkk , 2017).

Model fit mengukur seberapa baik suatu model struktural yang dihipotesiskan cocok dengan data empiris (Hair dkk, 2017). Suatu model dikatakan memiliki kecocokan yang baik jika nilai SRMR berada di bawah 0,08 (Hair dkk, 2017). Nilai SRMR yang dihasilkan oleh model dalam penelitian ini adalah 0,076 dimana nilai tersebut kurang dari 0,08 , artinya model memiliki kecocokan yang baik.

Nilai r-square $\left(\mathrm{r}^{2}\right)$ yang disajikan pada Tabel 3 menunjukkan bahwa variabel ATT memiliki nilai 0,204 artinya variabel ETK dan EPK dapat menerangkan variabel ATT sebesar 20,4\%. Pada variabel dependen BI nilai rsquare yang dihasilkan adalah sebesar 0,337, artinya variabel EPK, ETK, ATT, SN, PBC, GC, $\mathrm{PN}$, IM, dan BC dapat menerangkan variabel BI sebesar $33,7 \%$ dimana sisanya dipengaruhi oleh faktor lain di luar penelitian.

Predictive relevance $\left(\mathrm{Q}^{2}\right)$ yang disajikan pada Tabel 3 menunjukkan bahwa variabel ATT dan BI memiliki predictive relevance $\left(\mathrm{Q}^{2}\right)$ yang baik karena nilainya berada di atas 0 (Ghozali, 2014).

Selanjutnya, evaluasi model pengukuran dapat diukur dengan nilai koefisien jalur. Hasil koefisien jalur melalui proses boostrapping dari software SmartPLS 3.0 dapat dilihat pada Gambar 3.

Tabel 3. Nilai r-square dan predictive relevance

\begin{tabular}{lcc}
\hline \multicolumn{1}{c}{ Variabel } & r-square $\left(\mathbf{r}^{2}\right)$ & Predictive Relevance (Q \\
\hline Attitude Toward The Behavior (ATT) & 0,204 & 0,142 \\
\hline Behavioral Intention (BI) & 0,337 & 0,203 \\
\hline Environmental Practice Knowledge (EPK) & - & - \\
\hline Environmental Theory Knowledge (ETK) & - & - \\
\hline Government Companion (GC) & - & - \\
\hline Government Companion (GC) ${ }^{*}$ Subjective Norms (SN) & - & - \\
\hline Incentive Measures (IM) & - & - \\
\hline Past Behavior (PB) & - & - \\
\hline Perceived Behavioral Control (PBC) & - & - \\
\hline Personal Norms (PN) & - & - \\
\hline Subjective Norms (SN) & - & \\
\hline (Sumber: Pengolahan Data, 2020) & &
\end{tabular}




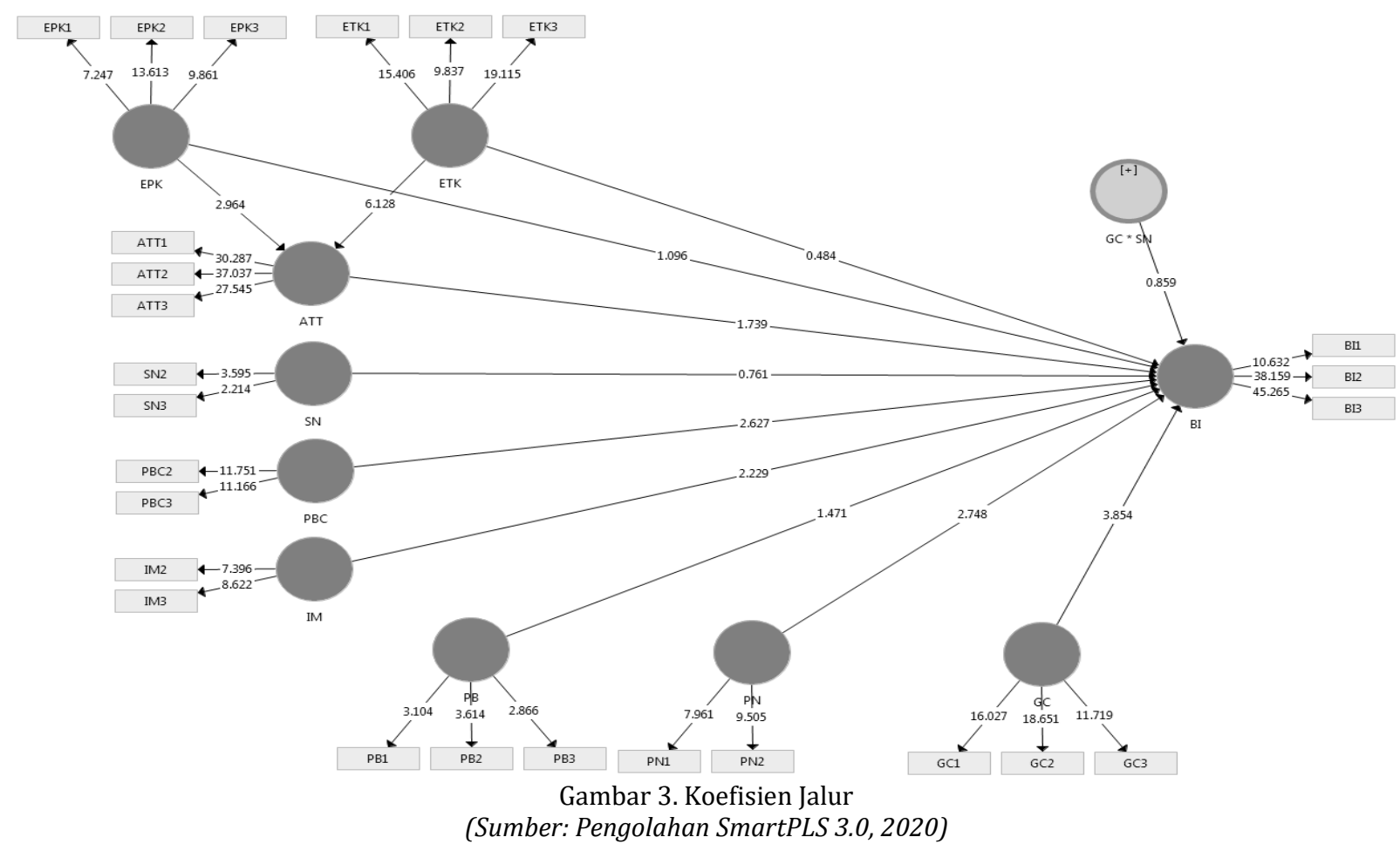

3.3 Analisis Hasil Hipotesis Penelitian

Pada bagian ini akan dijelaskan mengenai hasil pengujian hipotesis berdasarkan perhitungan PLS. Penilaian hipotesis ini dilihat berdasarkan nilai t-value dan p-value. Suatu hipotesis dapat diterima jika t-values $>1,96$ dan p-values $<0,05$ pada tingkat signifikansi 5\% (Hair dkk, 2017).

Tabel 4 memperlihatkan hasil uji hipotesis yang diajukan pada penelitian ini. Dari 11 hipotesis yang diajukan, terdapat 5 hipotesis penelitian yang diterima.

Tabel 4. Hasil Uji Hipotesis

\begin{tabular}{clcccc}
\hline Hipotesis & Hubungan & Original Sample (0) & T Values & P Values & Keputusan \\
\hline $\mathrm{H} 1$ & $\mathrm{ATT} \rightarrow \mathrm{BI}$ & 0,155 & 1,739 & 0,083 & Ditolak \\
\hline $\mathrm{H} 2$ & $\mathrm{SN} \rightarrow \mathrm{BI}$ & $-0,066$ & 0,761 & 0,447 & Ditolak \\
\hline $\mathrm{H} 3$ & $\mathrm{PBC} \rightarrow \mathrm{BI}$ & 0,163 & 2,627 & 0,009 & Diterima \\
\hline $\mathrm{H} 4$ & $\mathrm{IM} \rightarrow \mathrm{BI}$ & 0,159 & 2,229 & 0,026 & Diterima \\
\hline $\mathrm{H} 5$ & $\mathrm{ETK} \rightarrow \mathrm{BI}$ & 0,038 & 0,484 & 0,628 & Ditolak \\
\hline $\mathrm{H} 6$ & $\mathrm{ETK} \rightarrow \mathrm{ATT}$ & 0,384 & 6,128 & 0,000 & Diterima \\
\hline $\mathrm{H} 7$ & $\mathrm{EPK} \rightarrow \mathrm{BI}$ & 0,079 & 1,096 & 0,274 & Ditolak \\
\hline $\mathrm{H} 8$ & $\mathrm{EPK} \rightarrow \mathrm{ATT}$ & 0,217 & 2,964 & 0,003 & Diterima \\
\hline $\mathrm{H} 9$ & $\mathrm{GC} * \mathrm{SN} \rightarrow \mathrm{BI}$ & 0,098 & 0,859 & 0,391 & Ditolak \\
\hline $\mathrm{H} 10$ & $\mathrm{PN} \rightarrow \mathrm{BI}$ & $-0,191$ & 2,748 & 0,006 & Diterima \\
\hline $\mathrm{H} 11$ & $\mathrm{~PB} \rightarrow \mathrm{BI}$ & 0,117 & 1,471 & 0,142 & Ditolak \\
\hline
\end{tabular}

(Sumber: Pengolahan Data, 2020)

H1, H2, dan H3 merupakan faktorfaktor yang memengaruhi niat dan perilaku masyarakat dalam membuang sampah berdasarkan theory of planned behavior (TPB). Tabel 4 menunjukkan bahwa hanya $\mathrm{H} 3$ yang diterima $(\mathrm{t}=2,672>1,96$ dan $\mathrm{p}=0,009<$ 0,005) artinya bahwa Perceived Behavioral Control (PBC) secara signifikan memberikan pengaruh positif terhadap Behavioral Intention (BI) masyarakat untuk berpartisipasi dalam program Citarum Harum sebesar 16,3\%. Sedangkan Attitude Toward the Behavior $(\mathrm{t}=$ $1,739<1,96$ dan $\mathrm{p}=0,083>0,05)$ dan Subjective Norms $(\mathrm{t}=0,761<1,96$ dan $\mathrm{p}=$
$0,477>0,05)$ tidak memiliki pengaruh terhadap Behavioral Intention (BI) masyarakat untuk berpartisipasi dalam program Citarum Harum.

Incentive Measure (IM) merupakan faktor ekonomi yang memengaruhi perilaku seseorang. Tabel 4 menunjukkan bahwa Incentive Measure (IM) secara signifikan memberikan pengaruh positif terhadap Behavioral Intention (BI) masyarakat untuk berpartisipasi dalam program Citarum Harum $(\mathrm{t}=2,229>1,96$ dan $\mathrm{p}=0,026<0,05)$ sebesar $15,9 \%$. Hal tersebut selaras dengan penelitian yang dilakukan oleh (Line, Hanks, \& Miao, 
2017) yang menyatakan bahwa faktor ekonomi memiliki pengaruh yang dapat memengaruhi kebiasaan manusia yang berkaitan dengan lingkungan.

Environmental Theory Knowledge (ETK) memiliki pengaruh terhadap niat dan perilaku seseorang serta berpengaruh juga terhadap sikap seseorang terhadap lingkungan. Tabel 4 menunjukkan bahwa hanya H6 yang diterima dimana variabel Evironmental Theory Knowledge (ETK) signifikan memberikan pengaruh positif terhadap Attitude Toward the Behavior (ATT) masyarakat untuk berpartisipasi dalam program Citarum Harum $(\mathrm{t}=6,128>1,96$ dan $\mathrm{p}=0,000<0,05$ ) sebesar $38,4 \%$ sedangkan H5 tidak diterima $(\mathrm{t}=0,484<1,96$ dan $\mathrm{p}=0,628$ $>0,05)$. Hal tersebut selaras dengan penelitian yang dilakukan Yadaf \& Pathak (2016) yang menyatakan bahwa Environmental Theory Knowledge (ETK) memiliki pengaruh positif terhadap Attitude Toward Behavior (ATT).

Environmental Practice Knowledge (EPK) merupakan sikap positif dalam partisipasi masyarakat terhadap lingkungan. Tabel 4 menunjukkan bahwa EPK dapat berpengaruh secara langsung terhadap Behavioral Intention (H7) atau berpengaruh secara langsung terhadap Attitude Toward Behavior (H8). Berdasarkan hasil yang didapat pada Tabel 4, hipotesis 8 (H8) dapat diterima artinya Env (Line, Hanks, \& Miao, 2017)ironmental Practice Knowledge (EPK) secara signifikan memberikan pengaruh positif terhadap Attitude Toward the Behavior (ATT) masyarakat untuk berpartisipasi dalam program Citarum Harum $(\mathrm{t}=2,964>1,96$ dan $\mathrm{p}=0,003<0,05)$ sebesar $21,7 \%$. Sedangkan, H7 ditolak $(\mathrm{t}=1,096<1,96$ dan $\mathrm{p}=0,274>$ $0,05)$ artinya Environmental Practice Knowledge (EPK) tidak memberikan pengaruh terhadap Behavioral Intention (BI).

Tabel 4 menunjukkan bahwa $\mathrm{H} 9$ ditolak, artinya Government Companion (GC) tidak signifikan memberikan pengaruh positif langsung terhadap Subjective Norms (SN) masyarakat untuk berpartisipasi dalam program Citarum Harum $(\mathrm{t}=0,859<1,96$ dan $p=0,391>0,05$ ). Hal tersebut berarti bahwa regulasi ataupun himbauan dari pemerintah tidak memengaruhi perilaku masyarakat dalam membuang sampah ke sungai citarum.

Personal Norms (PN) merupakan norma sosial yang menjadi penentu seseorang dalam berperilaku. Berdasarkan uji hipotesis yang telah dilakukan, $\mathrm{H} 10$ dapat diterima $(\mathrm{t}=$ $2,748>1,96$ dan $\mathrm{p}=0,006<0,05$ ) sebesar 19,1\%. Hal tersebut dapat diartikan bahwa Personal Norms (PN) secara signifikan memberikan pengaruh positif terhadap Behavioral Intention (BI) masyarakat untuk berpartisipasi dalam program Citarum Harum.

Berdasarkan hasil uji hipotesis yang disajikan pada Tabel 4, dapat dilihat bahwa H11 ditolak $(\mathrm{t}=1,471<1,96$ dan $\mathrm{p}=0,142>$ 0,05). Dapat diartikan bahwa Past Behavior (PB) tidak signifikan memberikan pengaruh positif terhadap Behavioral Intention (BI) masyarakat untuk berpartisipasi dalam program Citarum Harum.

\section{KESIMPULAN}

Berdarsarkan hasil penelitian yang telah dilakukan, dapat disimpulkan bahwa faktorfaktor yang secara signifikan memengaruhi Behavioral Intention (BI) masyarakat untuk mewujudkan citarum harum adalah Perceived Behavioral Control (PBC), Incentive Measure (IM), dan Personal Norms (PN). Sedangkan faktor Environmental Theory Knowledge (ETK) dan Environmental Practice Knowledge (EPK) berpengaruh secara langsung terhadap Attitude Toward Behavior (ATT) masyarakat untuk berpartisipasi dalam program Citarum Harum.

\section{DAFTAR PUSTAKA}

Ajzen, I. (1985). From intentions to action: a theory of planned behavior. In Action Control (pp. 11-39).

Ajzen, I. (1991). The theory planned behavior: Organizational Behavior and Human Decission Process.

Ajzen, I. (2011). The theory of planned behavior: reactions and reflections. In Pyschology and Health (pp. 11131127).

Anas, P., Jubaedah, I., \& Sudino, D. (2017). Kualitas Air dan Beban Limbah Karamba Jaring Apung di Waduk Jatiluhur Jawa Barat. Jurnal Penyuluhan Perikanan dan Kelautan, 35-47.

BBWS, C. (2014). Menjadikan (Nama) Citarum Kembali Harum. bbwscitarum.com.

Erianti, D., \& Djelantik, S. (2019). Program Revitalisasi Sungai Citarum: Sebuah Analisis Strength, Weakness, 
Advocates, Advesaries (SWAA). Jurnal Ilmu Administrasi, 81-96.

Fryxell, G., \& Lo, C. (2003). The Influence of Enviromental Knowledge and Values of Managerial Behaviors on Behalf of The Environment: an Empirical Examination of Managers in China. Journal Bussines Ethic, 45-69.

Ghozali, I. (2014). Structural Equation Modeling Metode Alternatif Dengan Partial Least Least Square (2 ed). Semarang: Universitas Diponegoro.

Hair, J. F., Hult, G. T., Ringle, C. M., \& Sarstedt, M. (2017). A Primer on Partial Least Squares Structural Equation Modeling (PLS-SEM). United States of America: SAGE Publications, Inc.

Hair, J. F., Risher, J. J., Sarstedt, M., \& Ringle, C. M. (2019). When to use and how to report the results of PLS-SEM. European Business Review, 2-24.

Han, H. (2015). Travelers' pro-environmental behavior in a green lodging context: Converging value-belief-norm theory and the theory of planned behavior. Journal of Tourism Management, 164177.

Henseler, J., Ringle, C. M., \& Sarstedt, M. (2015). A new criterion for assessing discriminant validity in variance-based structural equation modeling. Journal of the Academy of Marketing Science, 115-135.

Hu, H., Zhang, J., Wang, C., Yu, P., \& Chu, G. (2019). What influences tourists' intention to participate in the Zero Litter Initiative in mountainous tourism areas: A case study of Huangshan National Park, China. Journal of Science of the Total Environment, 1127-1137.

Hu, H., Zhang, J., Yang, J., Yu, P., \& Chu, G. (2018). Factors influencing tourists' litter management behavior in mountainous tourism areas in China. Waste Management, 273-286.

Line, N. D., Hanks, L., \& Miao, L. (2017). Image Matters: Incentivizing Green Tourism Behavior. Journal of Travel Research, 114.

Pavita, K. D., Widiatmono, B. R., \& Liliyana, D. (2014). Studi Penentuan Daya Tampung Beban Pencemaran Sungai Akibat Buangan Limbah Domestik (Studi Kasus Kali Surabaya Kecamatan Wonokromo). Jurnal
Sumberdaya Alam dan Lingkungan, 2127.

Prinajati, P. D. (2019). Kualitas Air Waduk Jatiluhur Di Purwakarta Terhadap Pengaruh Keramba Jaring Apung. Journal of Community Based Environmental Engineering and Management, 79-86.

Schwartz, S., \& Howard, J. (1981). A Normative Decission-Making Model of Alturism. Alturism and Helping Behavior: Social, Personality and Developmenal Perspective., 189-211.

Syafila, M., \& Marselina, M. (2018). Strategi Pengelolaan Terpadu Untuk Penyelesaian Permasalahan Sungai Citarum: Perspektif Pemanfaatan Limbah Cair dari Segi Kualitas dan Kuantitas. In Strategi Pengelolaan Terpadu Penyelesaian Permasalahan Daerah Aliran Sungai Citarum (pp. 3045). Bandung: Forum Guru Besar ITB.

Van Ginkel, C. H., Ozerol, G., \& Lutfiandi. (2015). Water quality monitoring in the Upper Citarum River Basin: rethinking the role of stakeholders. 5th Environmental Technology and Management Conference "Green Technology towards Sustainable Environment".

Zakia, Agustina, D., Dewi, M. P., Ismowati, M., Vikaliana, R., \& Saputra, M. (2019). Mewujudkan Sistem Pengelolaan Sampah Melalui Program Citarum Harum. Jurnal Komunitas: Jurnal Pengabdian kepada Masyarakat, II, No. 1, Januari 2019, 38-43. 